ОРИГИНАЛЬНЫЕ СТАТЬИ / ORIGINAL PAPERS

DOI: $10.17073 / 2500-0632-2019-1-16-22$

\title{
Tendencies of Mining Technology Development in Relation to Deep Mines
}

\author{
Ngoc Minh Nguyen ${ }^{1}$, Duc Thang Pham ${ }^{2}$
}

\author{
${ }^{1}$ Central South University, Changsha, Hunan, China; Quang Ninh University of Industry, Quang Ninh, \\ Vietnam; \\ ${ }^{2}$ National University of Science and Technology "MISiS" (NUST "MISiS"), Moscow, Russia; \\ Quang Ninh University of Industry, Quang Ninh, Vietnam, \phamducthangmct@gmail.com
}

\begin{abstract}
Mineral demand rapidly increases; as a result, underground mining activities gradually dig into the earth's crust to deeper levels. For instance, the depth of coal mines has reached $1500 \mathrm{~m}$, whereas the depth of mines for nonferrous metals has already achieved around $4500 \mathrm{~m}$. Deep mining faces a number of technical and environmental challenges, first of all, great rock mass stresses, high temperature and long winding distance. The traditional technologies are hardly capable to provide the development and extraction efficiency and safety. That is why the need in developing and implementation of new modern mining technologies arose. In roadheading, TBM (tunnelboring machine) method is gradually introduced. A TBM combines the functions of rock breaking, support installation, mucking and conveying rock. In mining industry, smart mining based on mechanized and automated mining methods is successfully implemented at coal mines. Besides, a technical concept of fluidized mining for deepseated mineral resources (6000 $\mathrm{m}$ and more) was proposed. This paper presents the review of the current global status of deep mining and highlights some of the newest technological achievements in roadheading and the mineral extraction processes.
\end{abstract}

Keywords: mining technology, deep mines, smart mining, mechanized, extraction processes, fluidized mining.

For citation: Nguyen Ngoc Minh, Pham Duc Thang. Tendencies of mining technology development in relation to deep mines. Mining Science and Technology. 2019;4(1):16-22. DOI: 10.17073/2500-0632-2019-1-16-22.

\section{Направление развития технологий добычи применительно к рудникам глубокого заложения}

\section{Нгуен Нгок Минь ${ }^{1}$, Фам Дык Тхань ${ }^{2}$}

\section{${ }^{1}$ Центральный Южный Университет, Чанша, Хунань, Китай; Промышленный Университет Куанг Нинь, Куанг Нинь, Вьетнам;}

${ }^{2}$ Национальный исследовательский технологический университет «МИСиС», Москва, Россия; Промышленный Университет Куанг Нинь, Куанг Нинь, Вьетнам, \phamducthangmct@gmail.com

\begin{abstract}
Аннотация: Потребление полезных ископаемых быстро растет, что заставляет вести горные работы на всё более глубоких уровнях земной коры. В частности, глубина угольных шахт достигла 1500 м, а шахт для добычи цветных металлов - приблизительно 4500 м. Осуществление горных работ на больших глубинах требует решения ряда технических и экологических проблем, в первую очередь связанных с высокими давлениями и напряжениями в горном массиве, высокими температурами и значительными расстояниями транспортировки горной массы на поверхность. Традиционные технологии вряд ли способны обеспечить эффективность и безопасность разработки и добычи в таких условиях. Вот почему возникла необходимость в разработке и внедрении новых современных технологий добычи. В проходке горных выработок постепенно внедряется метод ТВМ (применение туннелепроходческих машин). Туннелепроходческая машина сочетает функции отбойки горной массы, установки крепи, уборки (из забоя), погрузки и транспортировки горной массы. В горнодобывающей промышленности «умная» добыча полезных ископаемых, основанная на механизированных и автоматизированных системах разработки, успешно применяется на угольных шахтах. Мы выдвигаем техническую концепцию добычи методом флюидизации/псевдоожижения горной массы для отработки глубокозалегающих ТПИ (6000 м и более). В данной статье представлен анализ текущего состояния разработки глубокозалегающих месторождений ТПИ в мире и освещены некоторые из
\end{abstract}


новейших технологических достижений в области проходки горных выработок и технологий добычи твердых полезных ископаемых.

Ключевые слова: технология добычи, глубокие рудники, «умная» добыча, механизированные процессы добычи/ведения горных работ, добыча методом флюидизации/псевдоожижения.

Для цитирования: Нгуен Нгок Минь, Фам Дык Тхань. Направление развития технологий добычи применительно к рудникам глубокого заложения. Горные науки и технологии. 2019;4(1):16-22. DOI: 10.17073/2500-0632-2019-1-16-22.

\section{Introduction}

Since coal and other mineral resources at shallow depths are gradually exhausted, underground mining activities gradually dig into the earth's crust to deeper levels. At present, deep mining at a depth of $1000 \mathrm{~m}$ is normal; the depth of coal mines, geothermal resources exploitation, nonferrous metal mines, and oil and gas production has reached 1500, 5000, 4500, and $7500 \mathrm{~m}$, respectively. Deep mining is likely to become the popular technique in the future. Coal mining in Poland, Germany, Britain, Japan, and France had reached depth of $1000 \mathrm{~m}$ and more in early 1980s. In China, there are 47 coal mines operating at a depth of $1000 \mathrm{~m}$ and more $[1,2]$. There were at least 80 mines for metals operating at a depth of $1000 \mathrm{~m}$ and more by 1996, mostly located in South Africa, Canada, the United States, India, Australia, Russia, and Poland. The average depth of mines for metals in South Africa ranges 2000 to $4000 \mathrm{~m}$ (Fig. 1) [3].

Activity of mining industry in China gradually changes to deeper levels to a depth ranging 1000 to $2000 \mathrm{~m}$, and it is already common to see the mines at this depth [4]. During the "The 13th Five-Year Plan" period, approximately 50 metal mines will operate at a depth of $1000 \mathrm{~m}$, and a half of them will reach the depth of $1500 \mathrm{~m}$ in the next 10 to 20 years (Fig. 2).

Deep mining faces a number of technical and environmental challenges, first of all, great rock mass stresses. If compatible mining methods would not adapted to high stress conditions, great technogenic disasters may happen, resulting in decreasing or even complete stoppage of the affected mine production. This will naturally produce extremely negative effect on the mine performance and viability. A large number of documents have showed that many deep metal mines have faced a large number of rock bursts, mine-shocks, formation of large areas of goaf instability, and roof caving problems. The second challenge when operating deep mines is high temperature. It is known that the temperature will rise by 10 to $40^{\circ} \mathrm{C}$ when digging to a depth of $1000 \mathrm{~m}$. The high temperature conditions of deep mining seriously affect the miner labor productivity and the effectiveness of cooling, thus increasing the mining cost. One more challenge is long winding distance: increasing mining depth requires increasing the height of winding of ore and all kind of materials, resulting in growing the mining cost and causing HSE risks.

Based on findings of the implemented research of deep mining status in the world, the authors summarized and highlighted relevant technologies applying to deep mining, namely, TBM (tunnel-boring machine use) for deep roadheading, smart mining, and fluidized mining.

\section{Application of TBM for deep roadheading}

It is well known that TBM is the most advanced tunneling machine in the world. A TBM combines the functions of rock breaking, support installation, mucking and conveying rock (Fig. 3) [5]. Compared with drill and blast method, TBM roadheading has significant advantages, including high support installation efficiency and lower project costs. TBM-based mining is more environmentally friendly and allows improving surrounding rock stability control [6]. 


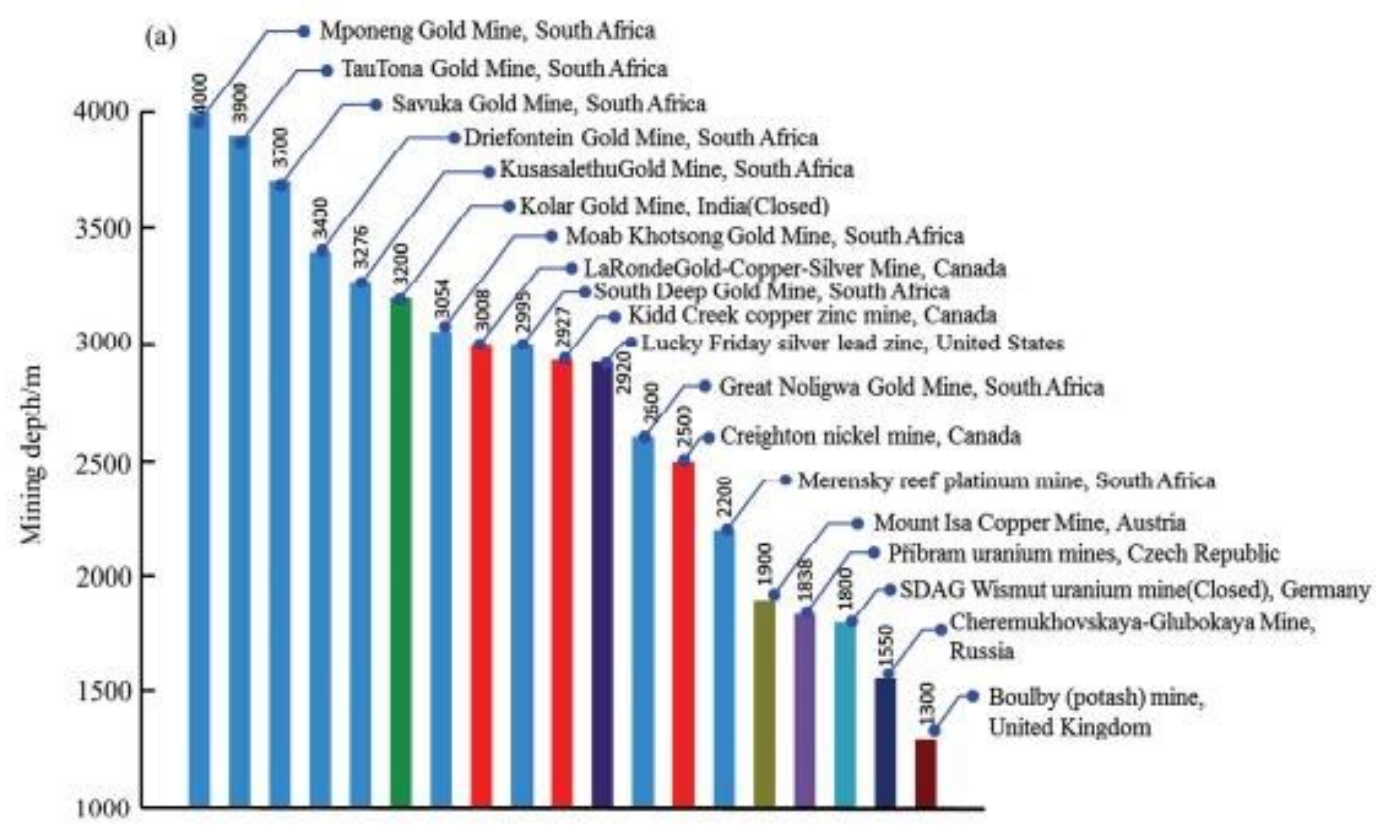

Fig. 1. Examples of Deep Mines in the World

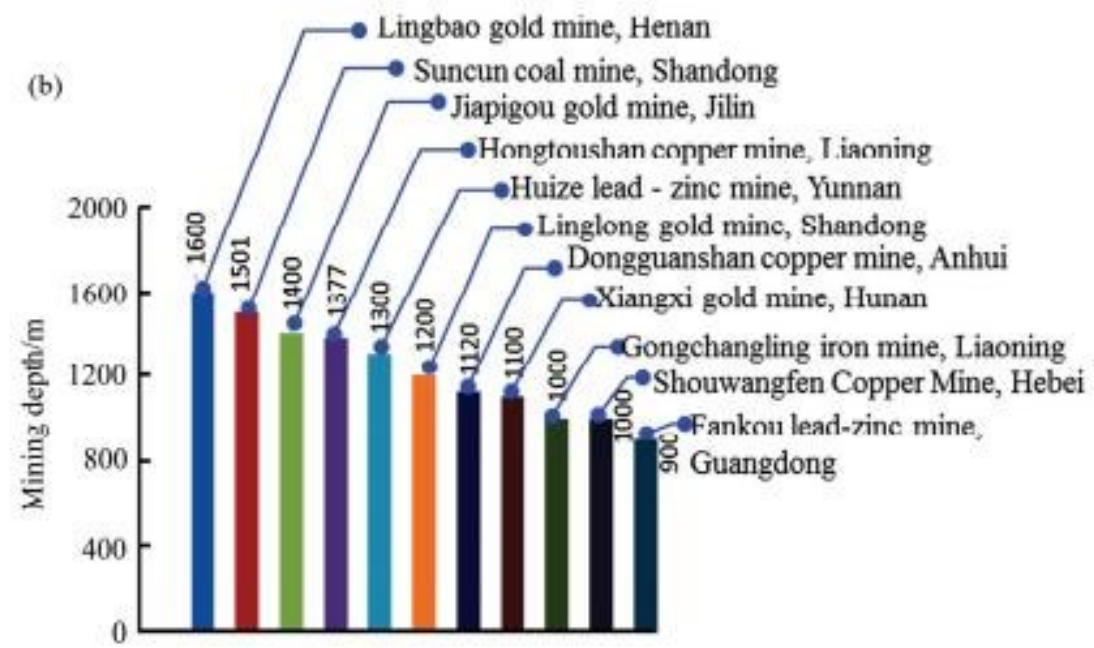

Fig. 2. Examples of Deep Mines in China

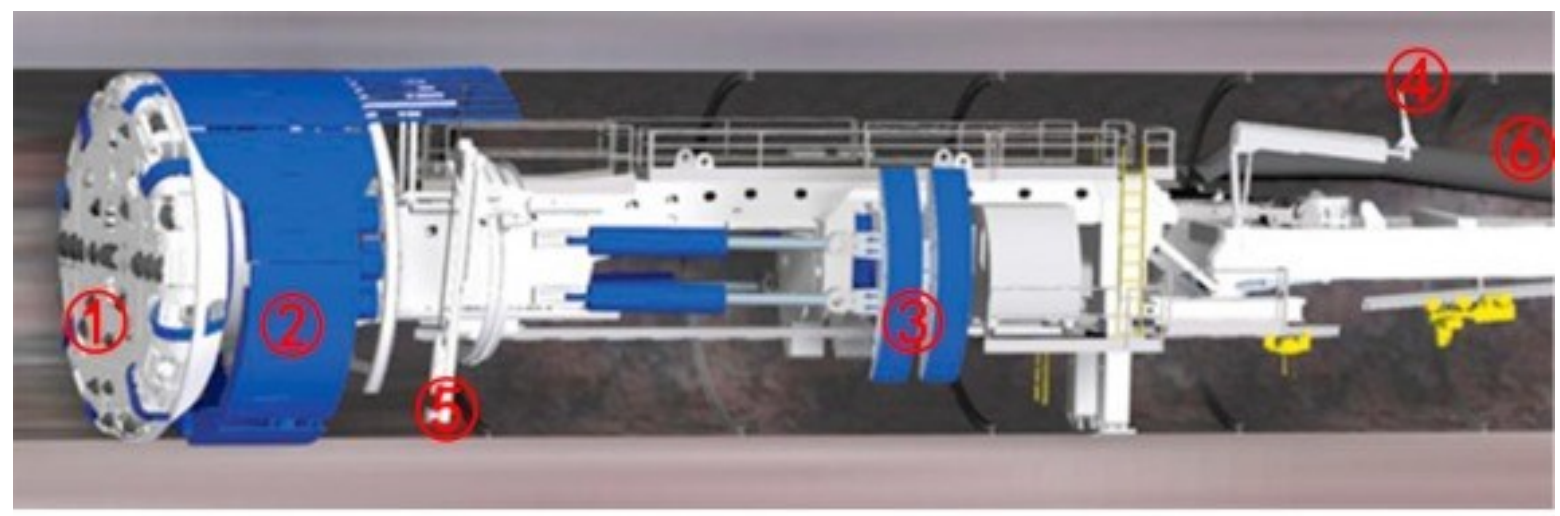

(1)Cutterhead (2)TBM head (3)Gripper (4)Guniting (5)Jumbolter (6)Belt conveyor

Fig. 3. A Gripper TBM (modified from The Robbins Company, 2015) 
Since the first modern TBM was developed and successfully applied in the 1950s, over 10,000 TBMs have been used to construct tunnels for traffic, hydropower, sewerage and water, underground storage and mining. The technique is currently available for tunneling at different diameters in different ground conditions from hard rock to soft soil. Based on ground and groundwater conditions (hard rock, soft soils, mixed and varying grounds), to provide stability of tunnel face and walls, TBMs can be broadly classified into seven types [7], as indicated in Fig. 4.

With increasing coal mining intensity, the number, length and depth of coal mine roadways increases drastically. The traditional drill-andblast method and comprehensive mechanized driving method, with corresponding support setting methods are incapable of controlling the surrounding rock stability. Hard rock TBMs (fullface tunnel boring machine) have significant advantages in terms of high advance rates, high support setting capacity; they are more environmentally friendly and enable lower tunneling costs. TBMs have been successfully used for some roadway tunneling and inclined shaft construction. Therefore, we can expect that the TBM tunneling method will become the first choice and preferred method for deep roadheading in coal mines in the future [8].
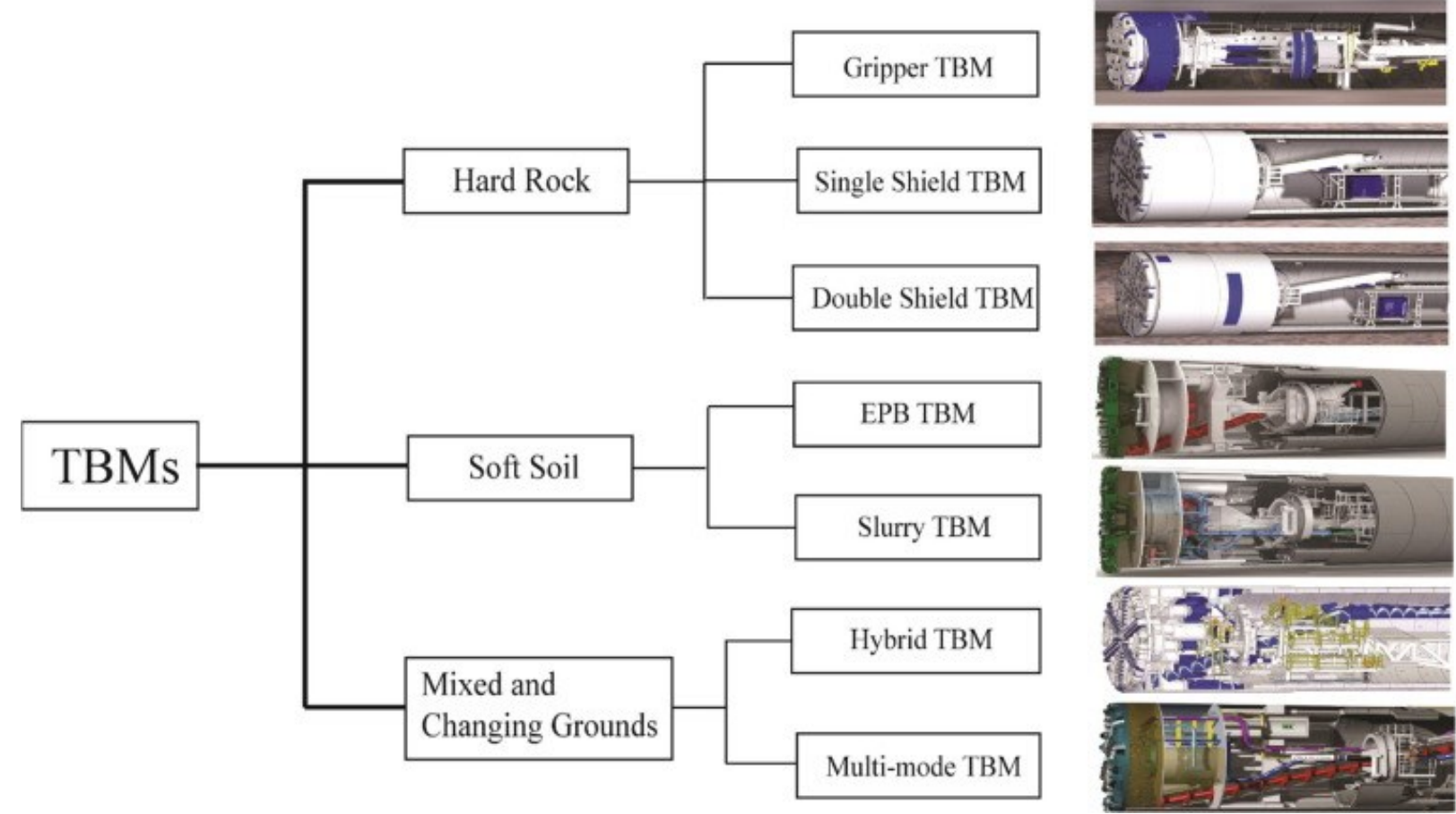

Fig. 4. A Classification of TBMs

\section{Smart mining}

Smart mining, based on mechanized and automatic mining methods and a combination of informatization with commercial development, has brought a revolution in the mining industry [9]. This new approach enables automatic mining based on smart control of a working face, mining machine operation, with automatic control of mining equipment. Smart mining has three main features: (1) mining machines can operate in automatic mode; (2) real-time data can be captured and updated promptly, including ge- ological information, coal-rock boundary location, positions of the machines and the face, etc.; and (3) mining machinery can be automatically controlled depending on the conditions of the working face. When decision-making process and machine operation can be conducted automatically, the working face is called "smart mining working face" [10].

In Australia, LASC (Longwall Automation Steering Committee) is engaged in automatic and smart mining method development for coal mines [11]. The LASC automation technologies 
are available for the national and international mining industry through the major OEM (Original Equipment Manufacturer) for longwall mining, which has integrated the LASC open intercommunication standards into its proprietary shearer automation equipment. The LASC technology has been widely adopted, with CSIRO (Mining Technology Research Group) automation technology deployed in more than $70 \%$ of the automated underground coal mining machinery operating in Australia, with growing the deployment in the world [12]. Three main advantages are provided by applying the precision optical fiber gyroscope and the method of navigation and orientation. The first one is threedimensional (3D) positioning of a shearer (at the deviation below $\pm 10 \mathrm{~cm}$ ); the second one is a system of straightening adjustment (at the deviation below $\pm 50 \mathrm{~cm}$ ); and the third advantage is a horizontal level control system for the working face. These three components compose the initial automatic controlling system. The mining process can be monitored and controlled remotely.

The IMSC is a remote monitoring and control system, used for control of working faces at longwall coal mining, which was developed by the American company Joy Global Inc. (recently taken over by the Japanese company Komatsu Mining Corp.). This system captures the realtime information and data from all mining machines at any time. It enables mining engineers to adjust coal production procedures based on the information reported by the system regarding alarms or breakdowns (Fig. 5) [13].

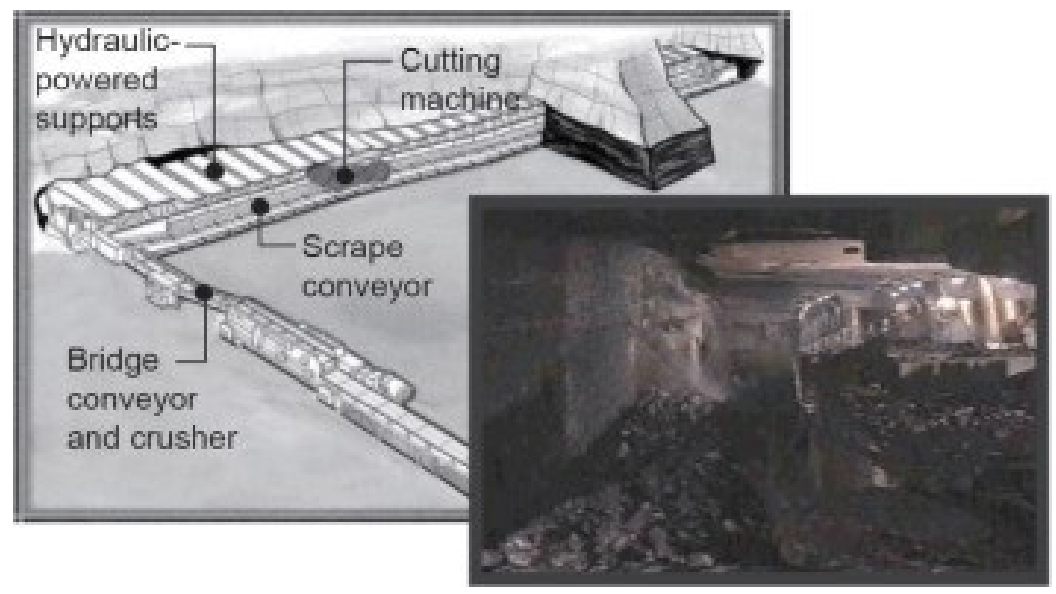

Fig. 5. Facilities at a Working Face Monitored by the IMSC

According to $\mathrm{Wu}$ et al. [14], the new task of a digital coal mine is to establish, for coal mines, a real-time access to digital mine integration platforms to create a multidimensional and dynamic coal mine virtual model prototype. Four main development directions are determined for digital mining in the new situation of deep mining: (1) a digital mine integration platform; (2) a mining simulation system; (3) underground positioning and navigation methods; and (4) mining environment smart perception.

\section{Fluidized mining}

Xie et al. $[15,16]$ assumed that there exists a theoretical limit of mining depth by traditional methods. It is estimated theoretically that all the currently available mining methods will become obsolete once the depth of underground mineral resources exceeds $6000 \mathrm{~m}$. Therefore, to implement development and utilization of mineral resources at great depths, disruptive innovations in mining theory and technology should be advanced. For this purpose, Xie et al. [16] proposed a theoretical and technical concept of fluidized mining for extraction of deep-seated mineral resources (Fig. 6). Based on a mining mode similar to the TBM, the concept provides for achieving in situ, real-time, and integrated utilization of deep-seated mineral resources through mining, sorting, refining, backfilling, power generation, and gasification of solid resources, thus converting the resources into gas, liquid, or a mixture of gas/liquid/solid substances. 


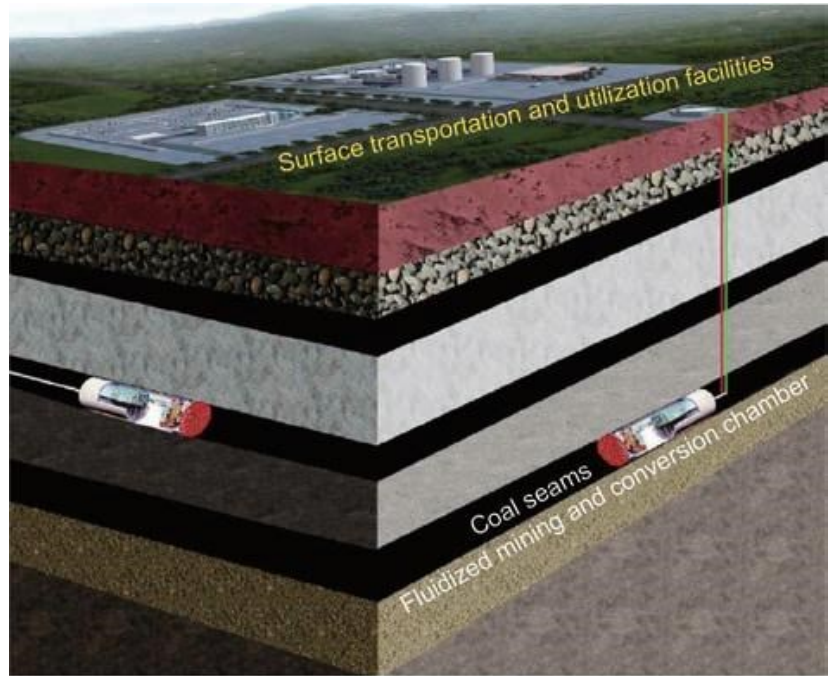

(a)

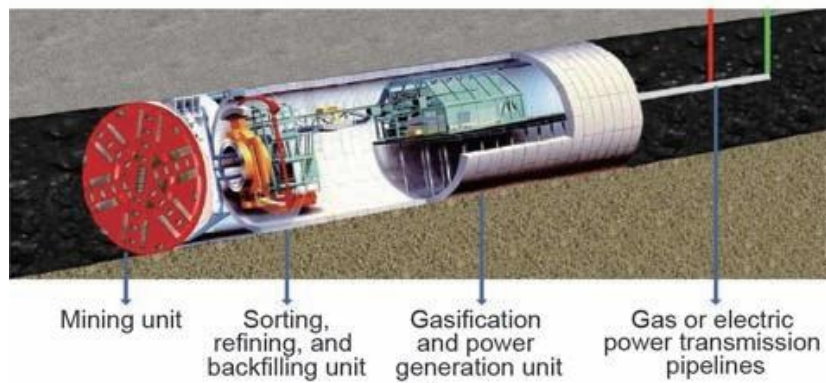

(b)

Fig. 6. A Conceptual Illustration of Fluidized Mining of Deep-Seated Mineral Resources.

(a) mining model; (b) fluidized mining and conversion facility

As a result, future coal mines will no longer have workers going down the mines, coal drawing, waste rock dumps, or dusting. Instead, power and energy transmission will be clean, safe, smart, environmentally-friendly.

For coal mining, the fluidized mining concept includes the following five main procedures: (1) unmanned breaking, (2) automated sorting, (3) fluidization of coal, (4) controlled backfilling, and (5) power transmission, smart power control, and power storage. For metal mining, the fluidized mining concept includes the following three steps: (1) unmanned breaking, (2) fluidization of ore, and (3) controlled backfilling [15].

There are four methods to implement the fluidized mining of deep-seated solid mineral resources: (1) the conversion of solid minerals into gases, such as underground gasification of coal; (2) the conversion of solid minerals into liquid fuels, such as the underground liquefaction of coal and high-temperature biological and chemical transformation of coal; (3) the conver- sion of solid minerals into mixes, such as explosive coal dust and water-coal slurry; and (4) the in situ conversion of solid minerals into electric power, such as the in situ underground production of coal-fired electric power. Fluidized mining is a disruptive innovation in mining technologies, particularly in regards to future deep mining.

\section{Conclusions}

This short review presents the current status of deep mining in the world, and highlights some of the newest technological achievements and opportunities. It also addresses some geotechnical issues in relation to deep mining. Some of the current challenges, advances, and expected issues in deep mining can be summarized as follows:

(1) Deep mining will be common in the future as coal and metal mineral resources at shallow depths gradually become exhausted. The progress is restricted and affected by the advancement of rock mechanics and machinebuilding technologies. New ideas and techniques 
are therefore required for deep mining, particularly considering great in situ and mininginduced stresses and other boundary conditions that are found at great depths.

(2) TBMs have significant advantages in excavation and support setting, and meet the deep roadheading requirements. Thus, TBM roadheading is believed to become the first choice and preferred future method for roadheading in deep mines.

(3) Smart mining methods using in longwall coal mining have been demonstrated their advantages for coal production because of their better return on investment, energy saving, safety, minimizing underground staff, and better performance.
(4) Fluidized mining for deep-seated coal resources is the novel idea, applicable to in-situ conversion of deep-seated mineral resources into gas, liquid, or a gas/liquid/solid mix to implement unmanned smart underground mining, sorting backfilling, and conversion into heat/power/syngas using an underground fluidized mining method and a conversion facility. The suggested method may replace the traditional resources breaking, transportation, and utilization modes with a new mining approach. In addition, the technique may pioneer the development of fluidized mining technology and facilitate achieving clean, efficient, and eco-friendly exploitation of deep-seated solid minerals.

\section{References}

1. Xie H., Gao F., Ju Y., Gao M., Zhang R., Gao Y., et al. Quantitative definition and investigation of deep mining. Journal of the China Coal Society, 40 (1) (2015), pp. 1-10.

2. Xie H. Research framework and anticipated results of deep rock mechanics and mining theory. Advanced Engineering Science, 49 (2) (2017), pp. 1-16.

3. Hu S., Peng J., Huang C., Chen P., Li M. An overview of current status and progress in coal mining of the deep over a kilometer. China Mining Magazine, 20 (7) (2011), pp. 105-110.

4. Li Xi-bing. Rock dynamics fundamentals and applications. Beijing, Science Press, 2014.

5. Barla G., Pelizza S. TBM tunnelling in difficult ground conditions. GeoEng2000 - An International Conference on Geotechnical \& Geological Engineering, Melbourne, Australia, 2000, p. 20 .

6. Liu Q. S., Huang X., Gong Q.M., et al. Application and development of hard rock TBM and its prospect in China. Tunnelling and Underground Space Technology, 57-2016, p.33-46.

7. Zheng Y. L., Zhang Q. B., Zhao J. Challenges and opportunities of using tunnel boring machine. Tunnelling and Underground Space Technology 57 (2016), pp. 287-299.

8. Xing H., Quansheng L., Kai S., Yucong P., Jianping L. Application and prospect of hard rock TBM for deep roadway construction in coal mines. Tunnelling and Underground Space Technology, 73 (2018), p. 105-126.

9. Wang J. H., Wang Y.G., Fu J. H. Crucial technology research and demonstration of digital mines. Journal of the China Coal Society, 41 (6) (2016), pp. 1323-1331.

10. Wang J. H., Huang Z. H. Innovation and development of intelligent coal mining science and technology in China. Coal Science and Technology, 42 (9) (2014), pp. 1-6.

11. Wang J. H., Huang L. T., Li S. B., Huang Z. H. Development of intelligent technology and equipment in fully-mechanized coal mining face. Journal of the China Coal Society, 39 (8) (2014), pp. 14181423.

12. He M., Zhang G., Wang G., Xu Y., Wu C., Tang Q. Research on mechanism and application to floor heave control of deep gateway. Chinese Journal of Rock Mechanics and Engineering, 28 (Suppl.1) (2009), pp. 2593-2598.

13. Wang J. H., Huang Z. H. The Recent Technological Development of Intelligent Mining in China. Engineering 3 (2017) 439 - 444.

14. Wu L., Wang Y., Ding E., Zhu W., Zhang R., Zhang S., et al. Thirdly study on digital mine: Serve for mine safety and intellimine with support from IoT. Journal of the China Coal Society, 37 (3) (2012), pp. 357-365.

15. Xie H., Gao F., Ju Y., Ge S., Wang G., Zhang R., et al. Theoretical and technological conception of the fluidization mining for deep coal resources. Journal of the China Coal Society, 42 (3) (2017), pp. 547-556.

16. Xie H., Ju Y., Gao F., Gao M., Zhang R. Groundbreaking theoretical and technical conceptualization of fluidized mining of deep underground solid mineral resources. Tunnelling and Underground Space Technology, 67(2017), pp. 68-70. 